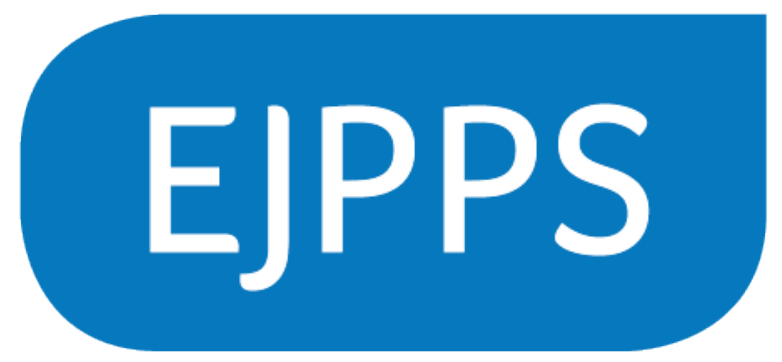

EUROPEAN JOURNAL OF
PARENTERAL AND
PHARMACEUTICAL SCIENCES

EJPPS - European Journal of Parenteral and Pharmaceutical Sciences Volume 26 Issue 1

https://www.ejpps.online/post/vol26-1-some-observations-on-protective-efficacy-of-surgicalclothing-systems

https://doi.org/10.37521/ejpps26102

Some observations on protective efficacy of surgical clothing systems with additional clothing components concerning airborne bacteriacarrying particles measured during ongoing surgery.

Bengt Ljungqvist and Berit Reinmüller

Building Services Engineering, Chalmers University of Technology,

Göteborg, Sweden

Corresponding Author: Berit Reinmüller

Email: beritr@chalmers.se 


\title{
Some observations on protective efficacy of surgical clothing systems with additional clothing components concerning airborne bacteria- carrying particles measured during ongoing surgery
}

\begin{abstract}
The main source of airborne bacteria-carrying particles is the staff and the patient. In order to reduce airborne bacteria-carrying particles from the staff, it is important that the surgical team wears a functional clothing system. This paper compares results from measurement studies of the protective efficacy, i.e., source strength, of a surgical clothing system with different additional clothing components. The studies were performed during ongoing surgery. The results show that the use of disposable hood or textile hood and the use of knee-length textile boots have considerable influence on the source strength, i.e., microbial air cleanliness in the operating room.
\end{abstract}

\section{Introduction}

The number of airborne bacteria-carrying particles, colony-forming units (CFUs), in the operating room is considered as an indicator of the risk of infections to the patient undergoing surgery susceptible to infections. To reduce surgical site infections, it is desirable to keep the bacteriacarrying particles at a low number in the operating room air, especially during orthopaedic prosthetic surgery.

Whyte et al (1) suggested that the air in the wound area should, on average contain no more that $10 \mathrm{CFU} / \mathrm{m} 3$ for surgery susceptible to infections. This level ( $\leq 10 \mathrm{CFU} / \mathrm{m} 3)$ is nowadays international accepted and often called ultraclean air. A technical specification, SIS-TS 39:2015 (2), published by the Swedish Standard Institute SIS, suggests half as large CFU-values as above.

The main source of airborne bacteria-carrying particles in an operating room is usually the personnel and patient, why the protective efficacy of the surgical clothing system concerning bacteria-carrying particles plays an important role on the microbial air cleanliness.

Measurements of airborne bacteria-carrying particles (aerobic CFUs) were performed in operating rooms during ongoing surgery to evaluate the protective efficacy, source strength, of a clothing system with various additional clothing components, such as disposable hood, textile hood, shoes without and with textile knee-length boots.

\section{Materia and methods}

\section{Apparatus}

Airborne viable particles were collected using a filter sampler (Sartorius MD8 ${ }^{\mathrm{TM}}$ ) and gelatine filters and a slit-to-agar sampler $\left(\mathrm{FH}^{\mathrm{TM}}\right)$. The gelatine filters had a pore size of less than $3 \mu \mathrm{m}$. The impaction STA-sampler had a $d_{50}$-value of less than $2 \mu \mathrm{m}$.

Each sampling period both instruments was 10 minutes. The sampling volumes were $1 \mathrm{~m}^{3}$ for the filter sampler and $0.5 \mathrm{~m}^{3}$ for the STA sampler. Both samplers were operated according to the manufactures' instructions. 
The microbial growth-medium used, incubation time and locations are described by Ljungqvist et al (3), where also a comparative study of the two measuring methods of collecting airborne viable particles is discussed.

The measurements of the comparative study (Ljungqvist et al (3)) were performed in operating rooms during ongoing orthopaedic surgery. The results show that the two measuring methods, filter method and impaction with the STA-sampler gave values $\left(\mathrm{CFU} / \mathrm{m}^{3}\right)$ in the same range. It was established with Mann-Whitney's U-test that there was no significant difference between the two measuring methods. These two methods with their difference in agar and incubation time are described as accepted methods in SIS-TS 39:2015 (2).

\section{Operating rooms}

The measurements were performed in operating rooms at hospitals in the Stockholm area. The tests were performed during ongoing orthopaedic surgery in two operating rooms, where the air movements could be characterised as dilution mixing, i.e., the dilution principle is applicable. The supply air was HEPA-filtered with air volume flows in the two operating rooms of $0.62 \mathrm{~m}^{3} / \mathrm{s}$ and $0.71 \mathrm{~m}^{3} / \mathrm{s}$, respectively, which for the two cases give about 18 air changes per hour.

\section{Clothing systems}

The surgical clothing systems used were Olefin clothing system with three variations of additional clothing components. The fabric Olefin consists of $98 \%$ olefin and $2 \%$ carbon fibre. The blouse with cuffs at arms and neck and trousers with cuffs at the wrists were laundered about 20 times, but not antimicrobial treated. The weight is $125 \mathrm{~g} / \mathrm{m}^{2}$. Disposable facemasks, sterile disinfected gloves, two types of headcovers and two different footwear were also worn.

The two types of head covering were common disposable hoods and textile hoods with cuffs at the face and pushbutton below the chin (laundered about 20 times). One footwear system had clean socks of cotton and disinfected plastic shoes, the other had textile knee-length boots over the shoes. The textile knee-length boots with zip at the back of the leg were laundered approximately 10 times. Photos of the different clothing components are shown in Figures 1 and 2.
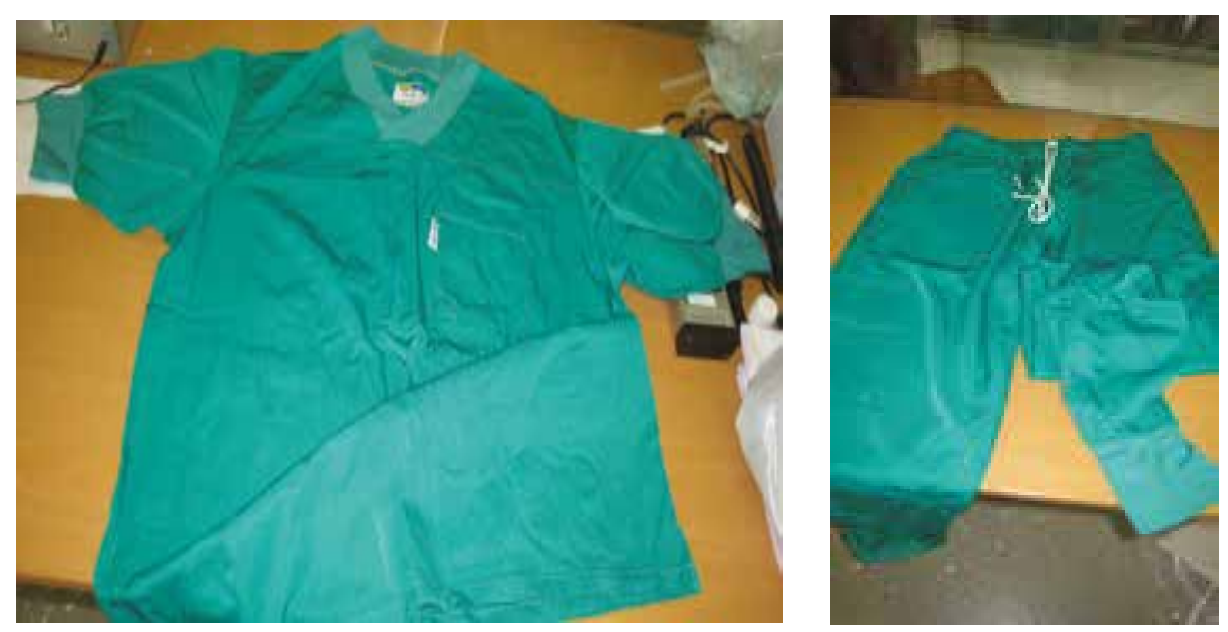

Figure $1 \quad$ Olefin surgical clothing system, blouse and trousers. 

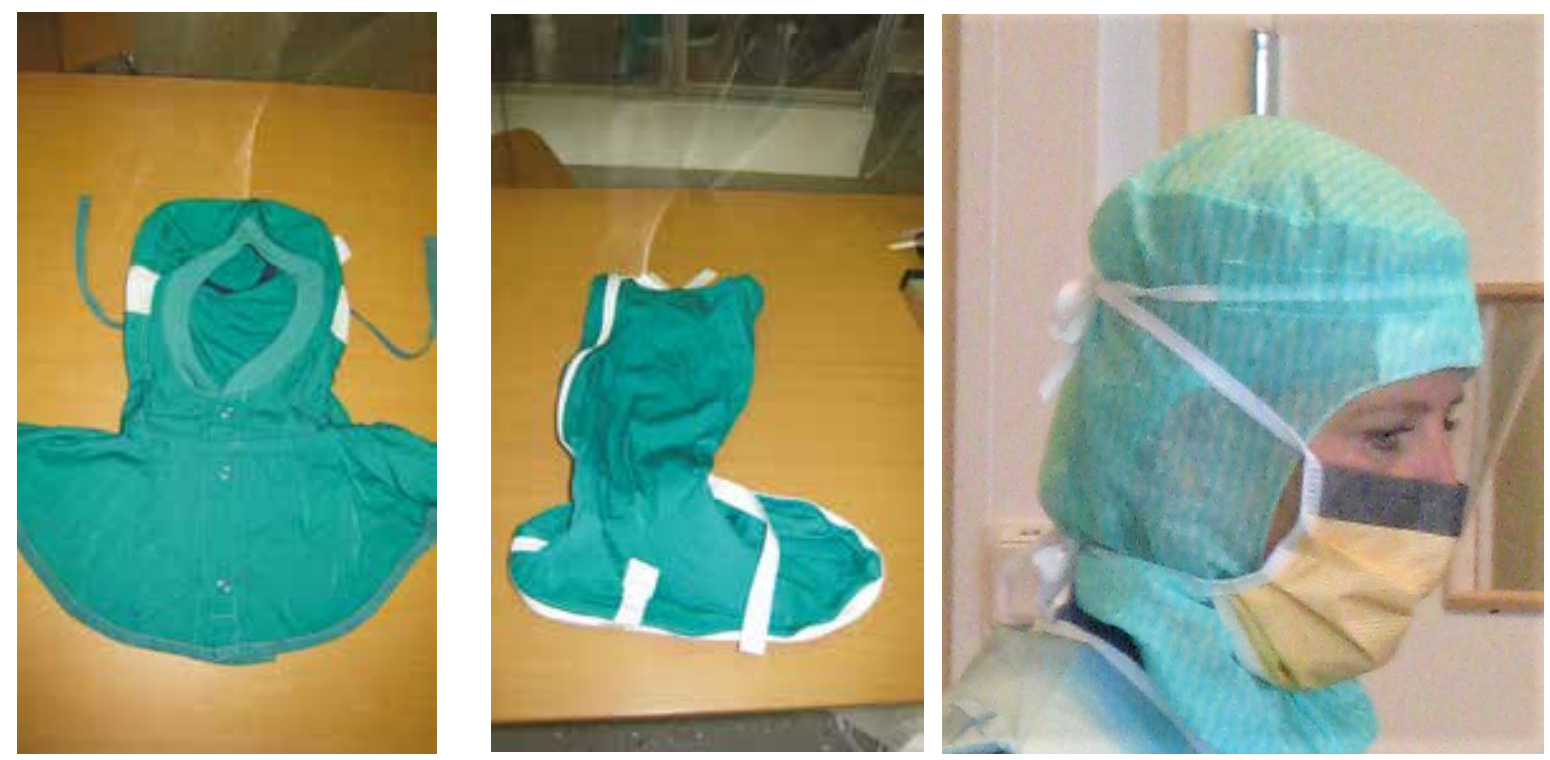

Figure 2 Olefin surgical clothing system, textile hood and textile knee-length boots, and the disposable hood.

The tests have been performed with the following three variations of clothing components:

1 Olefin clothing system with disposable hood and plastic shoes

2 Olefin clothing system with textile hood and plastic shoes

3 Olefin clothing system with textile hood and textile knee-length boots.

\section{Source strength}

With the assumption of no leakage into the operating room and the HEPA-filters having efficiency close to $100 \%$, the simplest possible expression, which is applied on the dilution principle, describe the source strength, protective efficiency of surgical clothing system (outward particle flow):

$$
\mathrm{q}_{\mathrm{s}}=\mathrm{c}+\mathrm{Q} / \mathrm{n}
$$

$$
\text { where } \quad \begin{array}{ll}
\mathrm{q}_{\mathrm{s}}= & \text { source strength, bacteria-carrying particles }(\mathrm{CFU} / \mathrm{s}) \\
\mathrm{c}= & \text { concentration, bacteria-carrying particles }\left(\mathrm{CFU} / \mathrm{m}^{3}\right) \\
\mathrm{Q} & =\text { total air flow }\left(\mathrm{m}^{3} / \mathrm{s}\right) \\
n & =\text { number of persons (number) }
\end{array}
$$

The source strength is here described as the mean value of the number of aerobic CFUs per second emitted from one person. Data are given as mean values based on several persons dressed in specific clothing systems. The source strength is a valuable tool in describing the protective efficacy of 
clothing systems against bacteria-carrying particles, e.g. a lower source strength gives a higher indication of a more suitable clothing system, (Ljungqvist et al $(4,5)$ ).

\section{Results}

Data from measurements with the filter sampler (Sartorius MD8) performed by Blomfeldt (6) are described by Kasina et al (7) during ongoing hip-joint operations in an operating room with dilution mixing air and an airflow of $0.62 \mathrm{~m}^{3} / \mathrm{s}$. The surgical team (6-8 persons) was dressed in Olefin clothing system with disposable hood and plastic shoes.

In Table 1 concentrations of aerobic CFU are given from eight relevant operations and estimation of the source strength mean values is described with aid of Equation (1).

Table 1 gives that the source strength mean value for Olefin clothing system with disposable hood and plastic shoes is $1.85 \mathrm{CFU} / \mathrm{s}$. This value should be compared to values less than and equal to $1.5 \mathrm{CFU} / \mathrm{s}$, which is the source strength level for clean air suits according to SIS-TS 39:2015 (2). To improve the source strength value for the Olefin system additional clothing components should be used.

Table $1 \quad$ Concentration of aerobic CFUs and estimated source strength during ongoing orthopaedic surgery with high activity (hip-joint) in an operating room with dilution mixing air and an airflow of $0.62 \mathrm{~m}^{3} / \mathrm{s}$. The surgical team was dressed in Olefin clothing systems with disposable hood and plastic shoes. Measurements were performed with the gelatine filter sampler (Sartorius MD8).

\begin{tabular}{|l|l|l|l|l|}
\hline $\begin{array}{l}\text { Operation } \\
\text { number }\end{array}$ & $\begin{array}{l}\text { Number of } \\
\text { persons }\end{array}$ & \multicolumn{2}{|l|}{ CFU concentration } & $\begin{array}{l}\text { Source strength* } \\
\text { (CFU/s) }\end{array}$ \\
\cline { 3 - 5 } & $\begin{array}{l}\text { Mean value } \\
\left(\mathrm{CFU} / \mathrm{m}^{3}\right)\end{array}$ & $\begin{array}{l}\text { Mean }- \text { Max } \\
\left(\mathrm{CFU} / \mathrm{m}^{3}\right)\end{array}$ & \\
\hline 1 & 6 & 37.0 & $20-57$ & 3.82 \\
\hline 2 & 6 & 2.7 & $0-6$ & 0.28 \\
\hline 3 & 6 & 20.7 & $1-40$ & 2.14 \\
\hline 4 & 6 & 7.3 & $1-18$ & 0.75 \\
\hline 5 & 8 & 35.2 & $22-48$ & 2.73 \\
\hline 6 & 8 & 24.5 & $14-40$ & 1.90 \\
\hline 7 & 8 & 8.0 & $2-16$ & 0.62 \\
\hline 8 & 6 & 25.0 & $10-46$ & 2.58 \\
\hline $\begin{array}{l}\text { Grand mean } \\
\text { value }\end{array}$ & 6.75 & 20.05 & -- & 1.85 \\
\hline
\end{tabular}

*Source strength values are given with two decimal places.

Ullmann et al (8) described measurements with the STA sampler when the surgical team (5-6 persons) had Olefin clothing system with textile hood and plastic shoes without and with textile knee-length boots over the shoes during ongoing orthopaedic surgery with high activity in an operating rooms with dilution mixing air and an airflow of $0.71 \mathrm{~m}^{3} / \mathrm{s}$. Concentrations of aerobic CFUs and estimated source strength with aid of Equation (1) are for the two cases shown in Table 2 and Table 3, respectively. 

orthopaedic surgery with high activity. in an operating room with dilution mixing air and an airflow of $0.71 \mathrm{~m}^{3} / \mathrm{s}$. The surgical team was dressed in Olefin clothing systems with textile hood and plastic shoes. Measurements were performed with the STA sampler (FH3) with the sampling time of airborne CFUs for 10 minutes per sample.

\begin{tabular}{|l|l|l|l|}
\hline Air sample number & Number of persons & $\begin{array}{l}\text { Concentration } \\
\left(\mathrm{CFU} / \mathrm{m}^{3}\right)\end{array}$ & $\begin{array}{l}\text { Source strength* } \\
(\mathrm{CFU} / \mathrm{s})\end{array}$ \\
\hline 1 & 6 & 4 & 0.47 \\
\hline 2 & 6 & 10 & 1.18 \\
\hline 3 & 6 & 10 & 1.18 \\
\hline 4 & 6 & 14 & 1.66 \\
\hline 5 & 5 & 12 & 1.70 \\
\hline $\begin{array}{l}\text { Mean } \\
\text { value }\end{array}$ & 5.8 & 10 & 1.24 \\
\hline
\end{tabular}

*Source strength values are given with two decimal places.

Table 3

Concentration of aerobic CFUs and estimated source strength during ongoing orthopaedic surgery with high activity. in an operating room with dilution mixing air and an airflow of $0.71 \mathrm{~m}^{3} / \mathrm{s}$. The surgical team was dressed in Olefin clothing systems with textile hood and with textile knee-length boots. Measurements were performed with the STA sampler (FH3) with the sampling time of airborne CFUs for 10 minutes per sample.

\begin{tabular}{|l|l|l|l|}
\hline Air sample number & Number of persons & $\begin{array}{l}\text { Concentration } \\
\left(\mathrm{CFU} / \mathrm{m}^{3}\right)\end{array}$ & $\begin{array}{l}\text { Source strength* } \\
(\mathrm{CFU} / \mathrm{s})\end{array}$ \\
\hline 1 & 5 & $<2$ & $<0.28$ \\
\hline 2 & 5 & $<2$ & $<0.28$ \\
\hline 3 & 5 & 2 & 0.28 \\
\hline 4 & 5 & 6 & 0.85 \\
\hline $\begin{array}{l}\text { Mean } \\
\text { value }\end{array}$ & 5 & $<3$ & $<0.42$ \\
\hline
\end{tabular}

*Source strength values are given with two decimal places.

Measurement with clothing system described in Table 2 and Table 3 have also been performed in a dispersal chamber and the source strength mean values without and with boots become $2.3 \mathrm{CFU} / \mathrm{s}$ and 1.0CFU/s, respectively, (Ullmann et al (8), Ljungqvist Reinmüller (9)).

The source strength mean value of a specific clothing system from operating room measurements during orthopaedic surgery with high activity (hip joint) seems to be about half the mean value obtained in dispersal chamber tests, see Ljungqvist et al(10,5), Ullmann et al (8) and Gandra (11). This gives, as a first approximation, an expected source strength mean value of $1.15 \mathrm{CFU} / \mathrm{s}$ for the system without boots and a mean value of $0.5 \mathrm{CFU} / \mathrm{s}$ for the system with textile boots.

These two values should be compared to the source strength mean values given in Table 2 and Table 3. It should be noted that these values fulfil the source strength level for clean air suits according to SIS-TS 39:2015 (2). 
Table 2 and Table 3 show that the reduction of the number of aerobic CFUs with boots compared to without boots is about two third. Even if the number of measurements during ongoing surgery is limited, the results indicate that the reduction during ongoing surgery is in the range as in the dispersal chamber tests.

Figure 3 shows exposed agar plates used in the measurements of airborne bacteria-carrying particles with the Olefin clothing system described in Tables 2 and 3. The upper four plates are showing the results from measurements with knee-length boots and the plates below are the results without knee-length boots.

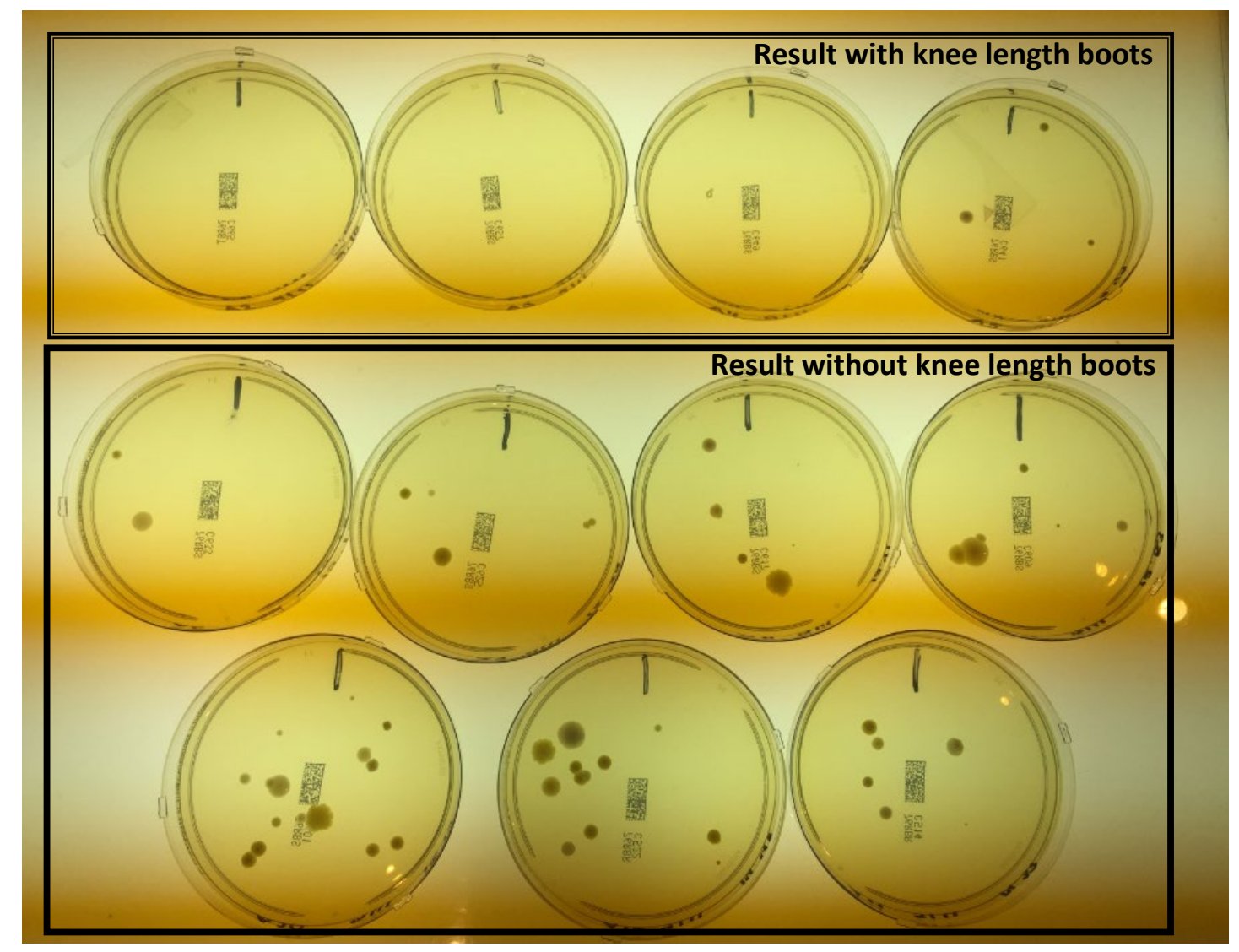

Figure 3 Agar plates used in the measurements of airborne bacteria-carrying particles in the operating room when the personnel are wearing the Olefin clothing system with textile hood and with and without textile knee-length boots (from Ullmann (12)).

\section{Discussion and conclusion}

Tables 1-3 show that the reduction of the number of aerobic CFUs is one third when the Olefin clothing system is used with textile hood instead of disposable hood and the total reduction becomes almost $80 \%$ when both textile hood and knee-length boots are used.

The difference in protective efficacy (source strength) between disposable hood and textile hood depends on how occlusive the fabrics are. The difference in poor size of the two fabrics are shown with microscopic photos in Figure 4. 

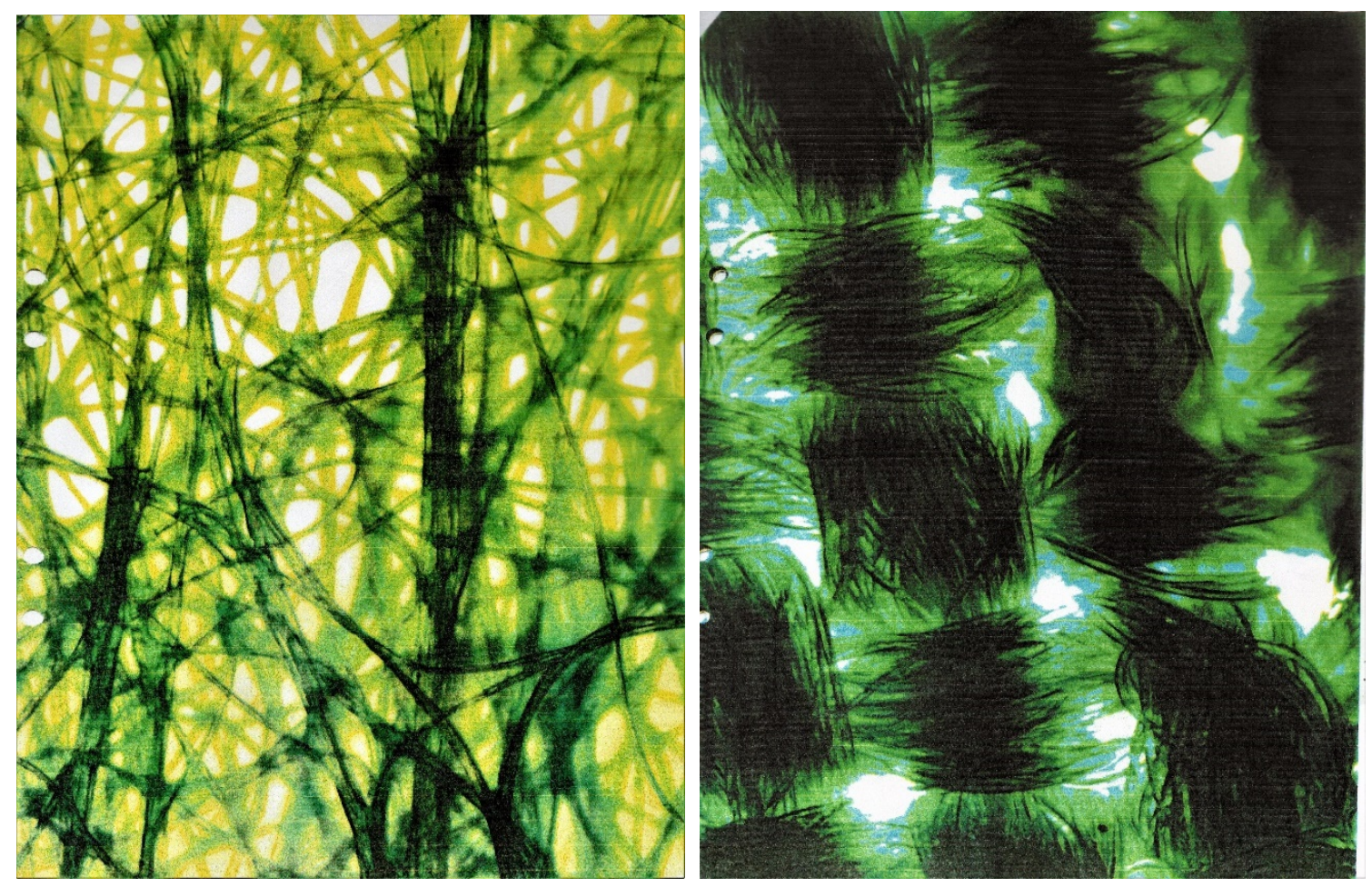

Figure 4 Disposable hood (left) and textile hood (right) seen under microscope with the same magnification.

It should be noted that the effect of knee-length boots is established in the pharmaceutical industry. Reinmüller (13) describes tests in an aseptic filling room for aseptic production of sterile products, where the operators were dressed in cleanroom coveralls and hoods, face masks and sterile gloves. The effect of knee-length textile boots compared to without knee-length boots was evaluated. When knee-length boots were used a reduction of airborne particles and aerobic CFUs of about $90 \%$ was achieved. The high reduction with cleanroom clothing might depend on that the cleanroom operator being better covered than the surgical staff within an operating room.

The theoretical mean value concentration of bacteria-carrying particles in an operating room can be calculated, when the dilution principle is applicable, if the total airflow, the number of people and their source strength are known. In this case, the Equation (1) becomes:

$$
c=n+q_{s} / Q
$$

In the following example, some estimations are given with Equation (2).

\section{Example:}

Calculate the mean value concentrations of bacteria-carrying particles (aerobic CFUs) during ongoing orthopaedic surgery with high activity in three different operating rooms with dilution mixing air and airflows of $0.6 \mathrm{~m}^{3} / \mathrm{s}, 1,5 \mathrm{~m}^{3} / \mathrm{s}$, and $2.5 \mathrm{~m}^{3} / \mathrm{s}$, respectively. The surgical team was six persons dressed in Olefin clothing system with different additional clothing components, three cases. 
Case $1 \quad$ Olefin clothing system with disposable hood and plastic shoes (Table 1).

Case 2. Olefin clothing system with textile hood and plastic shoes (Table 2).

Case 3. Olefin clothing system with textile hood and textile knee-length boots (Table 3).

The calculations are performed with Equation (2) and the numbers are given with one decimal place. The results are shown in Table 4

Table 4 Estimation of mean value concentrations of aerobic CFUs during ongoing surgery with high activity in three operating rooms with dilution mixing air and airflows of $0.6 \mathrm{~m}^{3} / \mathrm{s}$, $1,5 \mathrm{~m}^{3} / \mathrm{s}$, and $2.5 \mathrm{~m}^{3} / \mathrm{s}$, respectively. The surgical team (6 persons) were dressed in Olefin clothing system with different additional clothing components, see example.

\begin{tabular}{|l|c|c|c|c|}
\hline \multirow{2}{*}{$\begin{array}{l}\text { Olefin clothing } \\
\text { system }\end{array}$} & $\begin{array}{l}\text { Source strength* } \\
\text { (CFU/s) }\end{array}$ & \multicolumn{3}{|l|}{ Mean value CFU concentration* (CFU/m $\left.{ }^{3}\right)$} \\
\cline { 2 - 5 } & $\begin{array}{l}\text { Airflow } \\
0.6 \mathrm{~m}^{3} / \mathrm{s}\end{array}$ & $\begin{array}{l}\text { Airflow } \\
1.5 \mathrm{~m}^{3} / \mathrm{s}\end{array}$ & $\begin{array}{l}\text { Airflow } \\
2.5 \mathrm{~m}^{3} / \mathrm{s}\end{array}$ \\
\hline $\begin{array}{l}\text { Disposable hood } \\
\text { and plastic shoes }\end{array}$ & 1.9 & 19 & 7.6 & 4.6 \\
\hline $\begin{array}{l}\text { Textile hood and } \\
\text { plastic shoes }\end{array}$ & 1.2 & 12 & 4.8 & 2.9 \\
\hline $\begin{array}{l}\text { Textile hood and } \\
\text { textile knee- } \\
\text { length boots }\end{array}$ & 0.4 & 4 & 1.6 & 1 \\
\hline
\end{tabular}

*Source strength values and mean value concentrations are given to one decimal place.

The results in Table 4 show that use of additional clothing components can considerably improve the microbial air cleanliness in operating rooms during ongoing surgery.

It should be noted that the European Standard EN 13795-2:2019 (14) states that to manufacture a functional clean air suit, design shall also be considered. Arms and feet openings shall therefore be closed. A barrier hood should be worn, tucked into the gap at the neckline. If the clean air suit consists of blouse and trousers, the blouse should be tucked into the trousers or designed with a tightly fitting waist. In addition, it could be mentioned that the Swedish Standard SS 8760164:2020 (15) contains the construction pattern for all three parts (hood, blouse, trousers) of the clean air suit. 


\section{References}

1. Whyte, W., Lidwell, O. M., Lowbury, E. J. L., and Blowers, R., Suggested bacteriological standards for air in ultraclean operating rooms, Journal of Hospital Infection, 1983, 4, 133-139.

2. Swedish Standards Institute, SIS-TS 39:2015, Microbiological cleanliness in the operating room - Preventing airborne contamination - Guidance and fundamental requirements, Stockholm, Sweden, SIS:2015.

3. Ljungqvist, B., Reinmüller, B., and Tammelin, A., Comparison between two measuring methods with active air sampling of airborne viable particles, European Journal of Parenteral \& Pharmaceutical Sciences, 2012, 17(2), 56-59.

4. Ljungqvist, B., Reinmüller, B., Cleanroom Clothing Systems; People as a Contamination Source, River Grove, IL. PDA/DHI Publishing, 2004, ISBN:1-930114-58-3.

5. Ljungqvist, B., Reinmüller, B., Gustén, J., and Nordenadler, J., Performance of clothing systems in the context of operating rooms, European Journal of Parenteral \& Pharmaceutical Sciences, 2014, 19(3), 95-101.

6. Blomfeldt, A., M., The surgical clothing and surrounding factors affecting the amount of airborne bacteria in an operating room. - A matter of patient safety, Master thesis, (in Swedish), Sophia Hemmet Högskola, Stockholm, Sweden, 2014.

7. Kasina, P., Tammelin, A., Blomfeldt, A., M., Ljungqvist, B., Reinmüller, B., and Ottoson, C., Comparison of three distinct clean air suits to decrease the bacterial load in the operating room: an observational study, Patient Safety in Surgery, 10:1, 2016.

8. Ullmann, C., Ljungqvist, B., Reinmüller, B., Some aspects of protective efficacy of surgical clothing systems concerning airborne microorganisms based on results from measurements in a dispersal chamber and during surgical procedures, European Journal of Parenteral \& Pharmaceutical Sciences, 2017, 22(2), 51-58.

9. Ljungqvist, B. and Reinmüller, B., People as a Contamination Source, Performance of Olefin surgical clothing system in a dispersal chamber, Report 2016-1, Building Services Engineering, Chalmers University of Technology, Gothenburg, Sweden, 2016.

10. Ljungqvist, B., and Reinmüller, B., Clothing systems evaluated in a dispersal chamber, European Journal of Parenteral \& Pharmaceutical Sciences, 2014, 19(2), 67-69.

11. Gandra, P., Practical Safety Ventilation in Ultraclean Air Operating Rooms, Licentiate thesis, Building Services Engineering, Chalmers University of Technology, Gothenburg, Sweden, 2018.

12. Ullmann, C., Some Aspects on Contamination Control in Hospitals, Observations and Measurements, PhD-thesis, Dept of Architecture and Civil Engineering, Chalmers University of Technology, Gothenburg, Sweden, 2019.

13. Reinmüller, B., Dispersion and risk assessment of airborne contaminants in pharmaceutical clean rooms, PhD-thesis, Bulleting No 56, Building Services Engineering, KTH, Royal Institute of Technology, Stockholm, Sweden, 2001.

14. European Committee for Standardization, EN 13795-2:2019, Surgical clothing and drapes Requirements and test methods - Part 2: Clean air suits, Brussels, Belgium, CEN:2019.

15. Swedish Standards Institute SIS, SS 8760164:2020, Healthcare textiles - Operation textiles Reusable clean air suit, Stockholm, Sweden, SIS:2020. 


\section{Tables and Figures}

Table 1 Concentration of aerobic CFUs and estimated source strength during ongoing orthopaedic surgery with high activity (hip-joint) in an operating room with dilution mixing air and an airflow of $0.62 \mathrm{~m}^{3} / \mathrm{s}$. The surgical team was dressed in Olefin clothing systems with disposable hood and plastic shoes. Measurements were performed with the gelatine filter sampler (Sartorius MD8).

\begin{tabular}{|l|l|l|l|l|}
\hline \multirow{2}{*}{$\begin{array}{l}\text { Operation } \\
\text { number }\end{array}$} & \multirow{2}{*}{$\begin{array}{l}\text { Number of } \\
\text { persons }\end{array}$} & \multicolumn{2}{|l|}{ CFU concentration } & $\begin{array}{l}\text { Source strength* } \\
\text { (CFU/s) }\end{array}$ \\
\cline { 3 - 5 } & $\begin{array}{l}\text { Mean value } \\
\left.(\text { CFU/m })^{3}\right)\end{array}$ & $\begin{array}{l}\text { Mean }- \text { Max } \\
\left.(\text { CFU/m })^{3}\right)\end{array}$ & \\
\hline 1 & 6 & 37.0 & $20-57$ & 3.82 \\
\hline 2 & 6 & 2.7 & $0-6$ & 0.28 \\
\hline 3 & 6 & 20.7 & $1-40$ & 2.14 \\
\hline 4 & 6 & 7.3 & $1-18$ & 0.75 \\
\hline 5 & 8 & 35.2 & $22-48$ & 2.73 \\
\hline 6 & 8 & 24.5 & $14-40$ & 1.90 \\
\hline 7 & 8 & 8.0 & $2-16$ & 0.62 \\
\hline 8 & 6 & 25.0 & $10-46$ & 2.58 \\
\hline $\begin{array}{l}\text { Grand mean } \\
\text { value }\end{array}$ & 6.75 & 20.05 & -- & 1.85 \\
\hline
\end{tabular}

*Source strength values are given with two decimal places.

Table 2 Concentration of aerobic CFUs and estimated source strength during ongoing orthopaedic surgery with high activity. in an operating room with dilution mixing air and an airflow of $0.71 \mathrm{~m}^{3} / \mathrm{s}$. The surgical team was dressed in Olefin clothing systems with textile hood and plastic shoes. Measurements were performed with the STA sampler (FH3) with the sampling time of airborne CFUs for 10 minutes per sample.

\begin{tabular}{|l|l|l|l|}
\hline Air sample number & Number of persons & $\begin{array}{l}\text { Concentration } \\
\left(\mathrm{CFU} / \mathrm{m}^{3}\right)\end{array}$ & $\begin{array}{l}\text { Source strength* } \\
(\mathrm{CFU} / \mathrm{s})\end{array}$ \\
\hline 1 & 6 & 4 & 0.47 \\
\hline 2 & 6 & 10 & 1.18 \\
\hline 3 & 6 & 10 & 1.18 \\
\hline 4 & 6 & 14 & 1.66 \\
\hline 5 & 5 & 12 & 1.70 \\
\hline $\begin{array}{l}\text { Mean } \\
\text { value }\end{array}$ & 5.8 & 10 & 1.24 \\
\hline
\end{tabular}

*Source strength values are given with two decimal places. 

orthopaedic surgery with high activity. in an operating room with dilution mixing air and an airflow of $0.71 \mathrm{~m}^{3} / \mathrm{s}$. The surgical team was dressed in Olefin clothing systems with textile hood and with textile knee-length boots. Measurements were performed with the STA sampler (FH3) with the sampling time of airborne CFUs for 10 minutes per sample.

\begin{tabular}{|l|l|l|l|}
\hline Air sample number & Number of persons & $\begin{array}{l}\text { Concentration } \\
\left(\mathrm{CFU} / \mathrm{m}^{3}\right)\end{array}$ & $\begin{array}{l}\text { Source strength* } \\
(\mathrm{CFU} / \mathrm{s})\end{array}$ \\
\hline 1 & 5 & $<2$ & $<0.28$ \\
\hline 2 & 5 & $<2$ & $<0.28$ \\
\hline 3 & 5 & 2 & 0.28 \\
\hline 4 & 5 & 6 & 0.85 \\
\hline $\begin{array}{l}\text { Mean } \\
\text { value }\end{array}$ & 5 & $<3$ & $<0.42$ \\
\hline
\end{tabular}

*Source strength values are given with two decimal places.

Table $4 \quad$ Estimation of mean value concentrations of aerobic CFUs during ongoing surgery with high activity in three operating rooms with dilution mixing air and airflows of $0.6 \mathrm{~m}^{3} / \mathrm{s}$, $1,5 \mathrm{~m}^{3} / \mathrm{s}$, and $2.5 \mathrm{~m}^{3} / \mathrm{s}$, respectively. The surgical team (6 persons) were dressed in Olefin clothing system with different additional clothing components, see example.

\begin{tabular}{|c|c|c|c|c|}
\hline \multirow{2}{*}{$\begin{array}{l}\text { Olefin clothing } \\
\text { system }\end{array}$} & \multirow{2}{*}{$\begin{array}{l}\text { Source strength* } \\
\text { (CFU/s) }\end{array}$} & \multicolumn{3}{|c|}{ Mean value CFU concentration* (CFU/m³) } \\
\hline & & $\begin{array}{l}\text { Airflow } \\
0.6 \mathrm{~m}^{3} / \mathrm{s}\end{array}$ & $\begin{array}{l}\text { Airflow } \\
1.5 \mathrm{~m}^{3} / \mathrm{s}\end{array}$ & $\begin{array}{l}\text { Airflow } \\
2.5 \mathrm{~m}^{3} / \mathrm{s}\end{array}$ \\
\hline $\begin{array}{l}\text { Disposable hood } \\
\text { and plastic shoes }\end{array}$ & 1.9 & 19 & 7.6 & 4.6 \\
\hline $\begin{array}{l}\text { Textile hood and } \\
\text { plastic shoes }\end{array}$ & 1.2 & 12 & 4.8 & 2.9 \\
\hline $\begin{array}{l}\text { Textile hood and } \\
\text { textile knee- } \\
\text { length boots }\end{array}$ & 0.4 & 4 & 1.6 & 1 \\
\hline
\end{tabular}

*Source strength values and mean value concentrations are given to one decimal place.
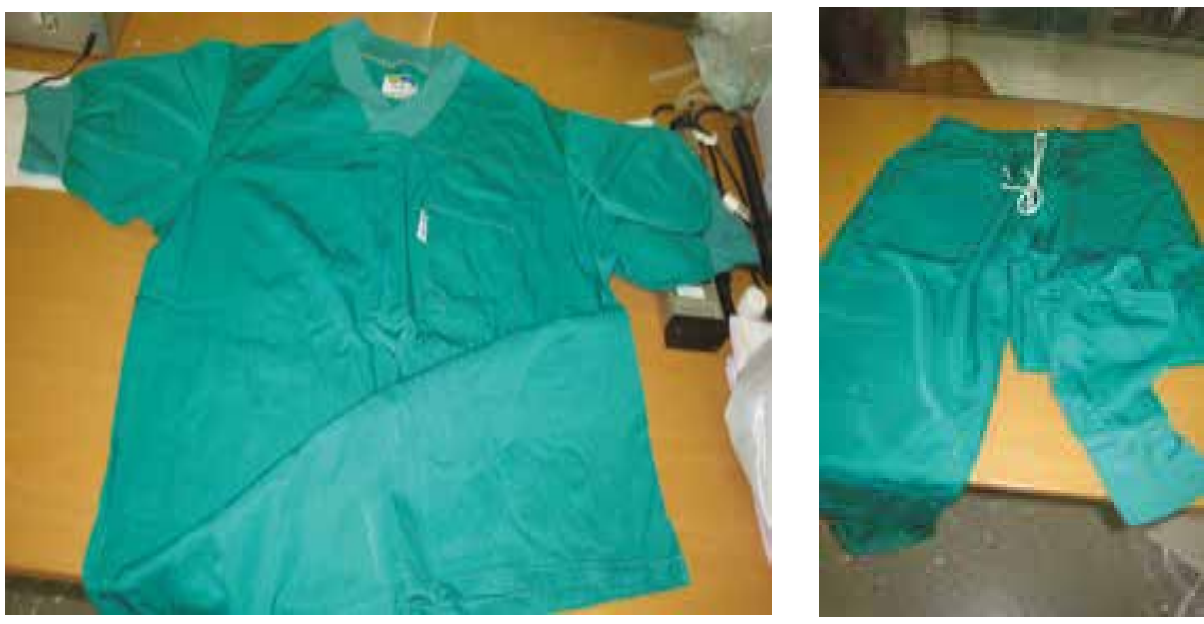

Figure $1 \quad$ Olefin surgical clothing system, blouse and trousers. 

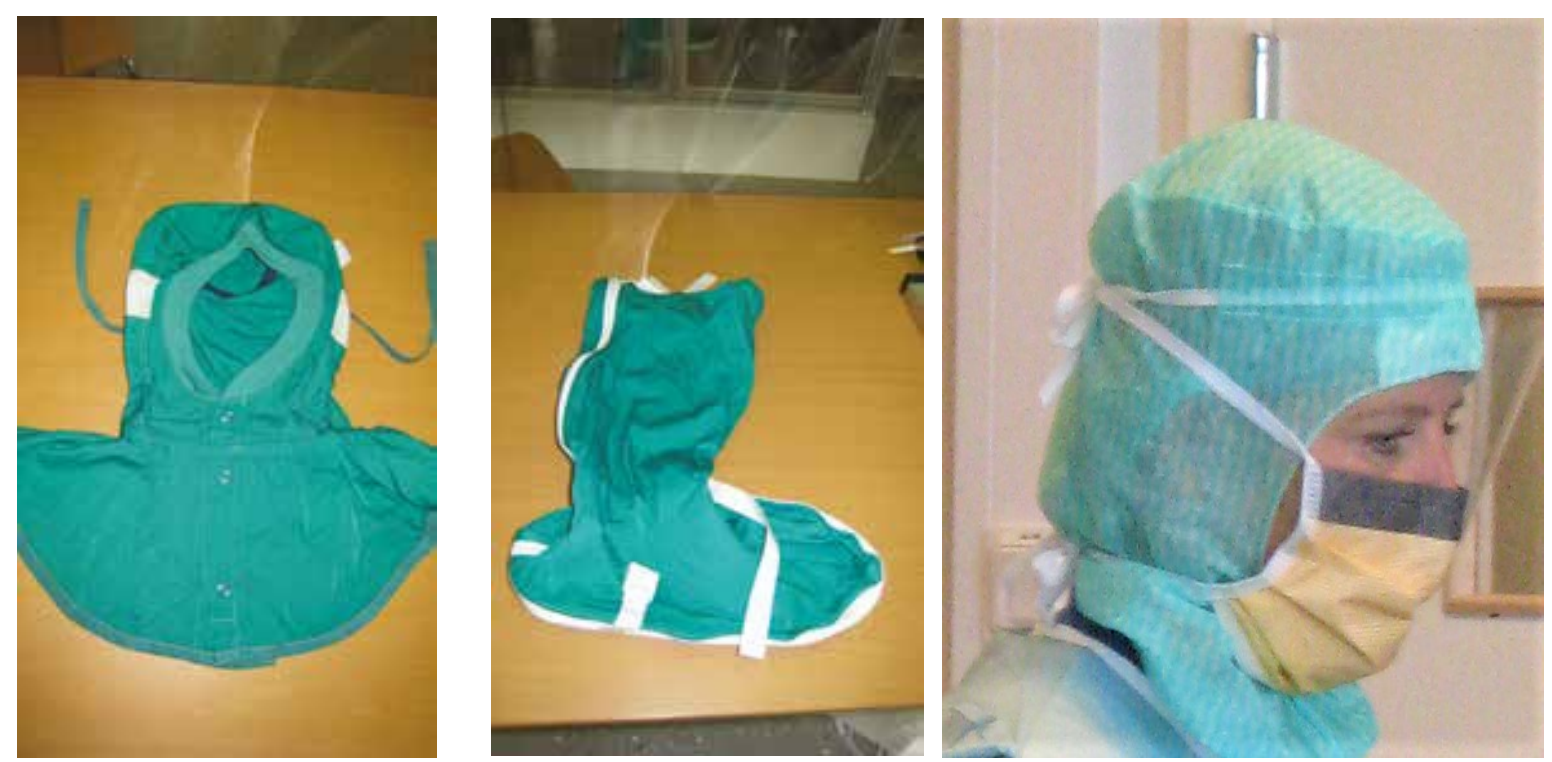

Figure 2 Olefin surgical clothing system, textile hood and textile knee-length boots and disposable hood 


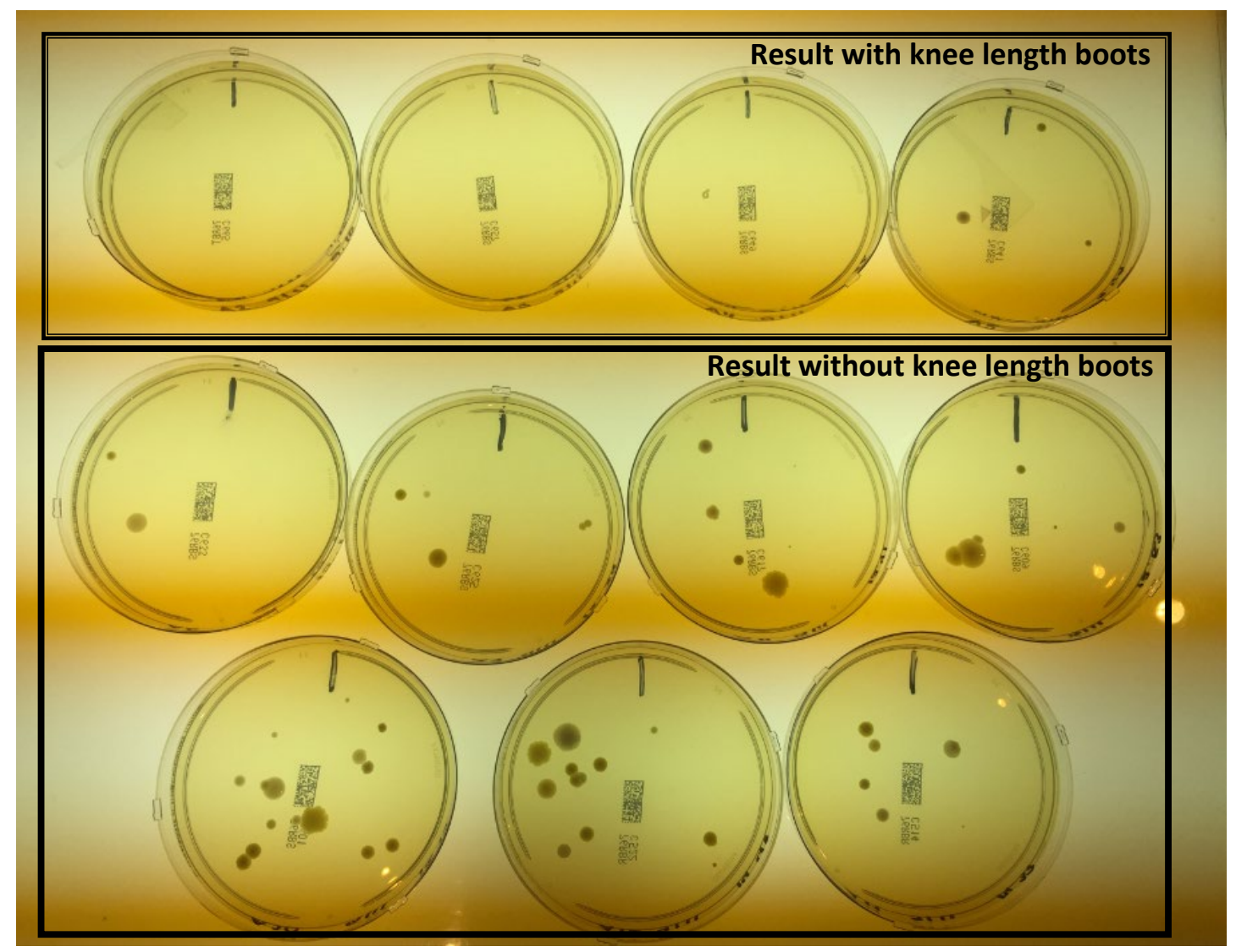

Figure 3 Agar plates used in the measurements of airborne bacteria-carrying particles in the operating room when the personnel are wearing the Olefin clothing system with textile hood and with and without textile knee-length boots (from Ullmann (12)).
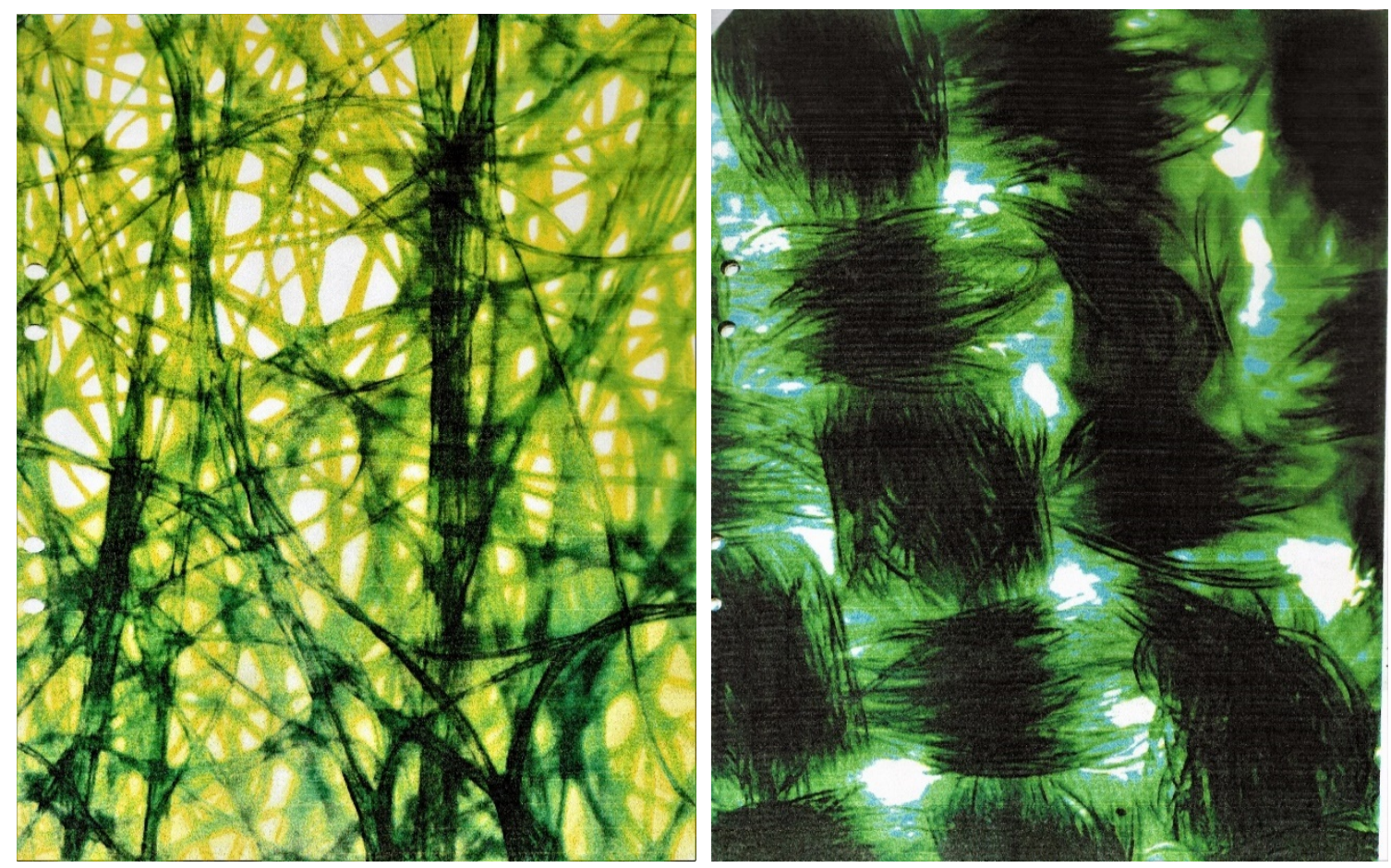

Figure 4

Disposable hood (left) and textile hood (right) seen under microscope with the same magnification. 